\title{
MIGRATION AND AGEING OF THE POPULATION OF THE CZECH REPUBLIC AND THE EU COUNTRIES
}

\author{
Markéta Arltová, Jitka Langhamrová*
}

\begin{abstract}
:
The population ageing is the main population problem of Europe. Population development may influence the economy and the economy may retrospectively influence population development. The consequences of this process may appear with a delay of several decades and they may have an unfavourable influence on the functioning of the economy and the prosperity of individual European countries. In connection with this, the international migration is often brought up, mainly the question whether the migration can solve or at least lessen the ramifications connected with the decrease in the number of population itself and population ageing. The migration itself is rather wide and extensive and cannot be dwelled upon in great detail, ergo we pointed out some of the ground ideas in this article, especially those which are most commonly connected with the demographic migration.
\end{abstract}

Keywords: migration, natural increase, age index, time series.

JEL Classification: J12, J13, C32

\section{Introduction}

Never before the European countries have had to deal with the problems linked to the demographic ageing of their population as intensively as at the current time. The demographic structure of the population has a fundamental influence on economic and social development and, on the contrary, the state of the economy has a retrospective influence on the demographic behaviour of the population. Although the consequences of this process may appear with a delay of several decades, they will have an unfavourable influence on the functioning of the economy and the prosperity of individual EU countries.

The population of the advanced countries will age. The first warning signals connected with ageing could be observed even before the beginning of the last decade of the $20^{\text {th }}$ century when the long-term decline in fertility began in Western Europe. In the majority of the advanced countries of Europe fertility has dropped below what is known as the preservation limit of simple reproduction. The population began to age relatively - there began to be more elderly people and fewer children. At the same

* Markéta Arltová, Jitka Langhamrová, University of Economics, Prague (arltova@ vse.cz;

langhamj@vse.cz). This paper was written with the support of the Grant Agency of the Czech Republic under No. 402/09/0369 "Modelling of Demographic Time Series in the Czech Republic" and of the long-term Research Project 2D06026, "Reproduction of Human Capital" financed by the Ministry of Education, Youth and Sport within the framework of National Research Program II. 
time also, in connection with the good living conditions of the inhabitants of advanced countries, mortality began to decline and the average lifespan began to lengthen. The population began to age absolutely - the number of old people rose. As a result of this there was a change in the age structure of the population. As it has already been said, the number of children began to drop and, on the contrary, there were more people in the older and oldest age-groups. This trend also appeared with a slight delay in the countries of the former Eastern block and it is still continuing at present all over Europe.

In the future it is possible to assume that the characteristic changes in demographic behaviour linked to the ageing will clearly be of a permanent nature. Considerations of the increasing fertility by means of a suitable pro-birth policy are not too realistic. Even from our recent history one can see that these measures have only a short-term effect (Arltová, Langhamrová, 2009). One of the possible solutions to this problem, therefore, is the maintenance of the number of the inhabitants and the reduction, or at least the maintaining, of the present level of their average age in some other way.

In this connection there is often questioned the advantage of foreign migration in the EU, i.e. whether the migration can resolve or at least lessen the consequences of the ageing. The problems of migration are very complex and it is impossible to deal with them in full here. In this article, therefore, only the basic ideas, which are most frequently linked with migration in demography, are mentioned. There are summarised the historical migratory waves, the state of migration in the EU25 countries (without Bulgaria and Romania) in the years 2004-2007 and their influence on the size and age of the populations of individual countries.

\section{Migration from a Historical Viewpoint}

Already in ancient times it was usual that people moved from place to place. The reasons for migration were most frequently religious, economic and military ones. Even in those times societies tried to regulate or control the influx of foreigners. The effort was not to accept certain groups at all. This concerned in particular the poor, the sick and the criminals. The exception was when those arriving brought wealth, knowledge, skills or culture. Even then the attitude of inhabitants to newcomers or to those who wished to come in was similar as today. Why people moved from one place to another had the most varied reasons. First of all they tried to move to land with better soil. They left territory where there were natural catastrophes and sometimes they left their territories for religious or political reasons.

Among the most significant waves of migration in medieval Europe we consider the "migration of nations" (in the $3^{\text {rd }}$ to $6^{\text {th }}$ centuries), the Arab invasion (in the $7^{\text {th }}$ and $8^{\text {th }}$ centuries) and also the western incursions of the Golden Horde of Genghis Khan in the $13^{\text {th }}$ century and the infiltration of the Turks into central Europe in the course of the $14^{\text {th }}$ and $16^{\text {th }}$ centuries. From the $17^{\text {th }}$ century there begins the migration of individuals and families as opposed to the migration of nations and specific groups. As towns gradually developed, people began to move mainly for economic reasons. Towns provided people with far better opportunities to earn a living than the countryside. In this period the desire for political and religious freedom also arose and the political organisation of the state undoubtedly played an important part. 
In the period from the $17^{\text {th }}$ century to the World War II there were massive migratory shifts. In the framework of the largest international wave of migration in history around 65 million people left Europe for North and South America and a further 17 million went to Africa and Australia.

The totalitarian systems of the twentieth century caused a new type of mass enforced migration in Europe. Over thirty million people were displaced or liquidated during the World War II. After the war there was the wave of the displacement of some 10 million Germans and their descendents from Eastern Europe. Enforced mass migration followed after the division of India and Pakistan, when almost 18 million people moved. The creation of Israel also gave rise to almost a million Palestinian refugees. Around 600,000 persons fled from the area after the end of the Vietnamese war and the Soviet invasion forced millions of Afghans to flee to Iraq and Pakistan.

The most significant migration wave in the post-war era is related to the Cold War and had played out between Eastern and Western Europe since the end of the Second World War up until 1989/1990. It culminated in times right after Communists had taken over in satellite states of the Union of Soviet Socialist Republics and particularly after 1956 in Hungary, in Czechoslovakia in 1968 and in Poland in 1980. Emigration of the most qualified and educated inhabitants constituted a serious problem for Communism and was in fact one of the main reasons for establishing one of the most absurd systems of restriction of free movement that human history has thus far experienced.

In the eighties and nineties of the $20^{\text {th }}$ century migratory waves continued in many parts of the world. Somalia and Ethiopia were afflicted not only by civil war, but also by drought, and so millions of people moved from the villages to the towns and even to neighbouring states. Hundreds of thousands of Kurds emigrated from Iraq to Turkey and Iran. Mass exodus of Eastern Germans in summer 1989 dramatically contributed to the collapse of communistic regime in Europe. The division of Yugoslavia also resulted in migration in the first half of the nineties not only within the state, but also on an international scale. Israel became a distinct destination of this time where thousands of Jews headed from the USSR (from Russia in particular) and from Ethiopia after the downfall of the local dictatorial regime. From this brief summary it is evident that migration can be forecast only with great difficulty. Something quite unexpected can happen that causes immense movements of the population. This is also clear from what is stated above as the last eight waves of migration took place in the last two centuries. Even though it is possible to assume that no such significant events will occur as might give rise to unexpected migration, we can expect migration in the future as a result of the increase in world population. This increase will take place first and foremost in the underdeveloped countries, whereas the populations of advanced countries are declining. The logical consequence will be the movement of immense masses of people to the advanced countries and therefore also into Europe. 


\section{Migration to the Countries of the European Union}

\subsection{Influence of Migration on the Numbers of Inhabitants in the Countries of the European Union}

In the past few centuries the number of those emigrating from Europe was several times greater than the number of immigrants arriving in Europe and this trend continued right up to the World War II. After the World War II and especially in the seventies of last century Europe became increasingly frequently the target destination. The increased influx of migrants in the $80^{6}$ s and 90 's of last century is also evident from Figure 1 (it depicts 25 of time series of the EU countries approximately constant migratory influx into the most countries and clearly illustrates an increased interest of migrants in some destinations during the observed time 1985-2007).

Figure 1

Net Migration to the Countries of the EU25 in the Years 1985-2007

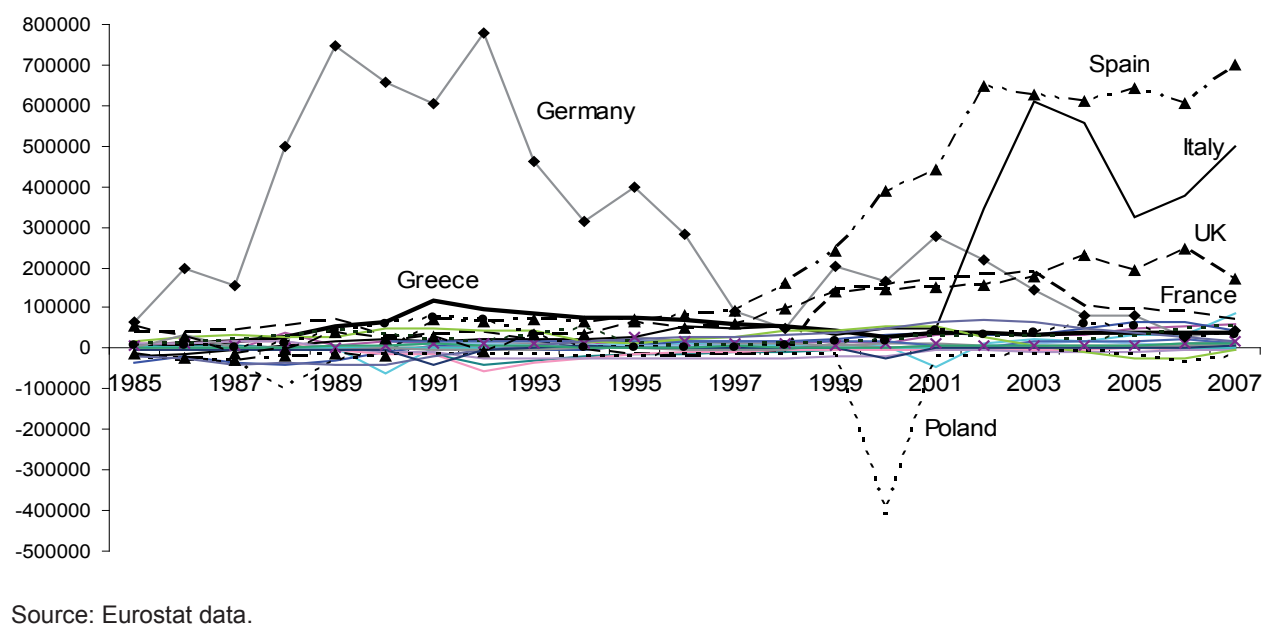

From the analysis of European migration trends (Gladišová, 2004) it emerged that at the beginning of this century there were around 19 million migrants registered in Europe. Of this number 6 million were citizens of EU states living on the territory of another EU state, roughly 3.5 million came from candidate countries (in particular Turkey, Poland and Romania), a further 2 million were from the lands of former Yugoslavia and roughly half a million from other European states (most often Russia and Albania). A further large group, counting around 3.3 million migrants, originated from Africa (Morocco, Algeria and Tunisia) and half a million from Asia (most frequently from India, Pakistan and China). The most frequent target countries for migrants were Germany (7.3 million persons, mostly from Turkey, Yugoslavia and Poland), then France (from Algeria and Tunisia), the Great Britain (4 million, mainly from India and Pakistan), Italy (from Albania) and Spain (from the countries of Latin America). From the point of view of the composition of the immigrant population 
there were clear historical and geographical connections with the colonial past and, even though this principle was not generally applicable, it is evident from the above that in some states there was a strong prevalence of migrants from a certain country.

After the expansion of the European Union in 2004 to include states of the former Eastern bloc we can see relatively considerable changes in this trend (Figure 1). If we take into account the index of net migration (the difference between the number moving in and moving out), then in the years 2004-2007 most migrants went to Spain (2.55 million), Italy (1.75 million) and the Great Britain $(839,000)$. High values were also still achieved by France $(359,000)$ and Germany $(234,000)$, even though the data show a very marked loss of interest in both countries throughout this period. Of the traditional target countries we can see the greatest change in Holland, where 60,000 more citizens left the country than arrived in it. If we concentrate on the new members of the EU it is very interesting, especially from our point of view, that the greatest influx of migrants was recorded by the Czech Republic $(173,000)$ and on the table of the "most attractive" target countries of the EU25 it took $9^{\text {th }}$ place in front of such countries as Portugal and Sweden. In the other countries (with the exception of Lithuania and Latvia) one can see a slow increase in the interest of migrants. Poland stands traditionally outside this trend and we can designate it rather as a source country, as from 2004 approximately 80,000 more people left the country than arrived in it (from the year 2000 the drop in the Polish population is actually 537,000).

Table 1

Net Migration in the EU25 in 2004 and 2007

\begin{tabular}{|c|c|c|c|c|c|}
\hline Country & 2004 & 2007 & Country & 2004 & 2007 \\
\hline Spain & 610,036 & 700,048 & Hungary & 18,162 & 14,568 \\
\hline Italy & 556,582 & 497,096 & Slovenia & 1,719 & 14,250 \\
\hline UK & 227,158 & 171,722 & Finland & 6,721 & 13,877 \\
\hline Czech Republic & 18,635 & 83,945 & Cyprus & 15,724 & 7,390 \\
\hline France & 105,000 & 72,531 & Slovakia & 2,874 & 6,793 \\
\hline Belgium & 35,759 & 62,327 & Luxembourg & 4,396 & 6,001 \\
\hline Sweden & 25,326 & 53,978 & Malta & 1,920 & 1,720 \\
\hline Ireland & 47,620 & 46,239 & Estonia & 134 & 160 \\
\hline Germany & 81,827 & 45,224 & Lithuania & $-1,079$ & -642 \\
\hline Greece & 41,388 & 40,014 & Netherlands & $-9,960$ & -907 \\
\hline Austria & 61,726 & 31,382 & Latvia & $-9,612$ & $-5,244$ \\
\hline Denmark & 4,962 & 20,229 & Poland & $-9,382$ & $-20,485$ \\
\hline Portugal & 47,282 & 19,500 & & & \\
\hline
\end{tabular}

Source: Eurostat data.

If we look at these data in a wider context, in the European Union at the time of its expansion as of 1 January 2004 there were 459.2 million inhabitants on the territory of the 25 member states and at the beginning of 2008 there were already 468.2 million. With regard to the fact that in the majority of countries (apart from France, the Great 
Britain, Spain and Ireland) there is stagnation in the natural growth of the population thanks to the small natural increase in the number of inhabitants (Figure 2) and that in Estonia, Italy, Lithuania, Latvia, Hungary, Germany and Portugal the natural increase has long been negative (Table 2), the increment in the number of inhabitants of the EU countries can be accounted unequivocally to migration.

Figure 2

Natural Increase in the Countries of EU25 in the Years 1985-2007

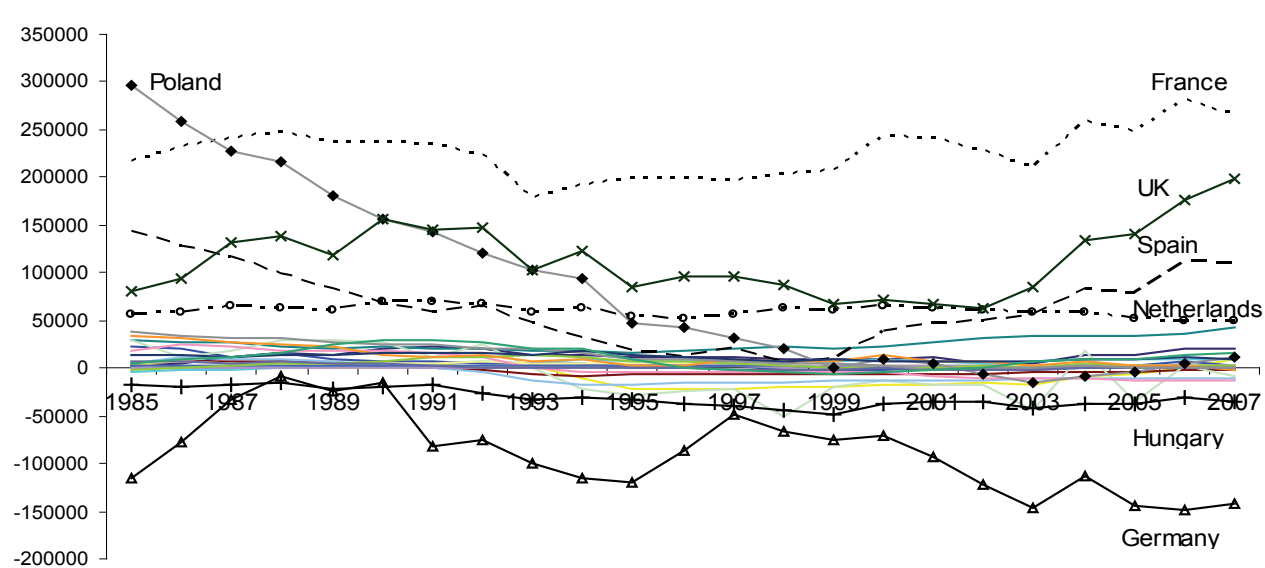

Source: Eurostat data.

Table 2

Natural Increase in EU25 in 2004 and 2007

\begin{tabular}{|c|c|c|c|c|c|}
\hline Country & 2004 & 2007 & Country & 2004 & 2007 \\
\hline France & 258,387 & 264,969 & Austria & 4,676 & 1,625 \\
\hline UK & 132,914 & 197,558 & Luxembourg & 1,874 & 1,611 \\
\hline Spain & 82,657 & 108,580 & Slovenia & -562 & 1,239 \\
\hline Netherlands & 57,454 & 48,314 & Malta & 881 & 760 \\
\hline Ireland & 33,821 & 42,570 & Slovakia & 1,895 & 568 \\
\hline Belgium & 13,672 & 20,005 & Portugal & 7,288 & $-1,020$ \\
\hline Sweden & 10,396 & 15,692 & Estonia & $-3,693$ & $-1,634$ \\
\hline Poland & $-7,391$ & 10,647 & Italy & 17,548 & $-9,093$ \\
\hline Czech Republic & $-9,513$ & 9,996 & Lithuania & $-11,690$ & $-9,769$ \\
\hline Finland & 10,158 & 9,652 & Latvia & $-10,921$ & $-13,278$ \\
\hline Denmark & 8,803 & 8,478 & Hungary & $-37,355$ & $-35,325$ \\
\hline Cyprus & 3,084 & 3,184 & Germany & $-112,649$ & $-142,293$ \\
\hline Greece & 713 & 2,031 & & & \\
\hline
\end{tabular}

Source: Eurostat data. 
The overall increment in the number of inhabitants is given by the sum of the natural increase and net migration. The development of both indices in total for the EU25 countries is shown by Figure 3.

Figure 3

Natural Increase and Increase through Migration in a the EU25

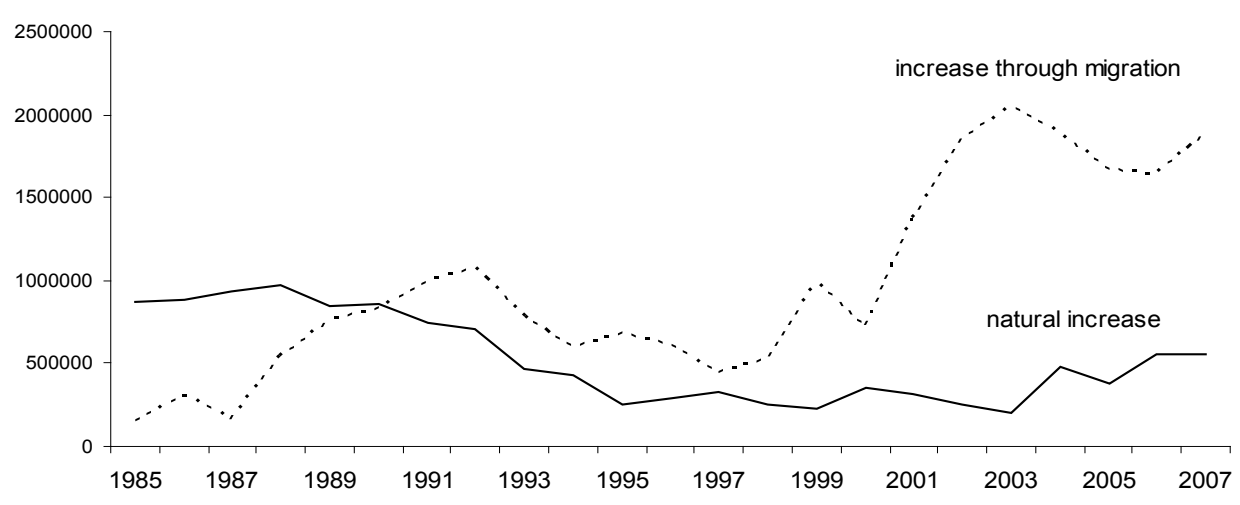

Source: Eurostat data.

From Table 3 it is evident that in the years 2004-2007 the natural increase accounted for approximately one quarter of the increase in the number of inhabitants of the European Union; in 2005 it was actually just under 16\%.

Table 3

Share of the Natural Increase and the Increase through Migration in the Total Increase in the Number of Inhabitants of the EU25 in 2004-2007

\begin{tabular}{|l|c|c|}
\hline EU 25 & Natural increase & Increase through migration \\
\hline $\mathbf{2 0 0 4}$ & $21.14 \%$ & $78.86 \%$ \\
\hline $\mathbf{2 0 0 5}$ & $15.91 \%$ & $84.09 \%$ \\
\hline $\mathbf{2 0 0 6}$ & $27.12 \%$ & $72.88 \%$ \\
\hline $\mathbf{2 0 0 7}$ & $25.39 \%$ & $74.61 \%$ \\
\hline
\end{tabular}

Source: Eurostat data + own calculations.

If we take into account only these two indices, then it is obvious that migration has been increasing in importance, especially in the last four years. Thanks to the high value of net migration the majority of the member states register an increase in the number of inhabitants. The increased migration to some countries eliminates the negative or small natural increase of inhabitants and thus there is no decrease in the total number of inhabitants. This applies, for instance, to Italy and Portugal in 2007. In Estonia, Hungary and Germany, however, even migration is not saving the falling number of inhabitants; net migration is relatively low (Table 1) and is unable to compensate for the natural decline in the inhabitants (Table 2) of these countries. In the case of Lithuania, Latvia and Poland there is actually a drop in the number of 
inhabitants not only on the basis of the natural reduction in inhabitants, but also due to the increased emigration from these countries to other countries of the European Union.

\subsection{Influence of Migration on Ageing of Inhabitants of the Countries of the European Union}

In connection with migration there is very often mentioned another unfavourable demographic trend of the present - the ageing of the population in the advanced European countries. The problem of migration is linked to the question whether it is possible to resolve or at least lessen the consequences of the ageing through migration.

In recent years several studies have been carried out on the influence of migration on fertility in EU countries. In one of the latest studies Sobotka (2008) analyses the influence of migrants on the total number of births and compares the birth rate of migrating women with the birth rate of women of the host country. He points to the fact that, although some groups of migrants head for Europe from countries with very high overall fertility, in the host country there is gradual assimilation and adaptation to local customs and it implies also a reduction in the difference between the fertility of the immigrant and domestic women. Therefore, although migration helped to increase the number of babies born in some countries (such as in the Great Britain, France, Spain and Austria) and there was also an increase in the share of births of immigrant women in the total number of births, the influence of immigrant women on the level of overall fertility in the individual countries is still relatively small (usually between 0.05 and 0.10 ).

The negligible influence of migration on the fertility of women in the EU countries can also be observed from the analysis of the index of ageing (the proportion of persons over the age of 65 years per 100 children up to the age of 15), through which we will document the gradual ageing of European population.

Figure 4 shows the index of ageing and the shares of the age groups 0-14 and 65+ in the population of the EU25 countries. It is evident that since the eighties of last century there has been a sharp decline in Europe in the proportion of children up to the age of 15 as a result of the reduction in the fertility of women and the slow increase in the proportion of persons over the age of 65 as a result of the lengthening of the average lifespan.

Since 2004, when the two shares were balanced and the index of ageing of the EU25 countries reached the value of 100, a higher proportion of older persons prevailed in the European population. This brings and will bring in the future higher economic and social costs for this group of inhabitants. 
Figure 4

Index of Ageing and the Shares of the Age Groups 0-14 and 65+ in the Population of the EU25

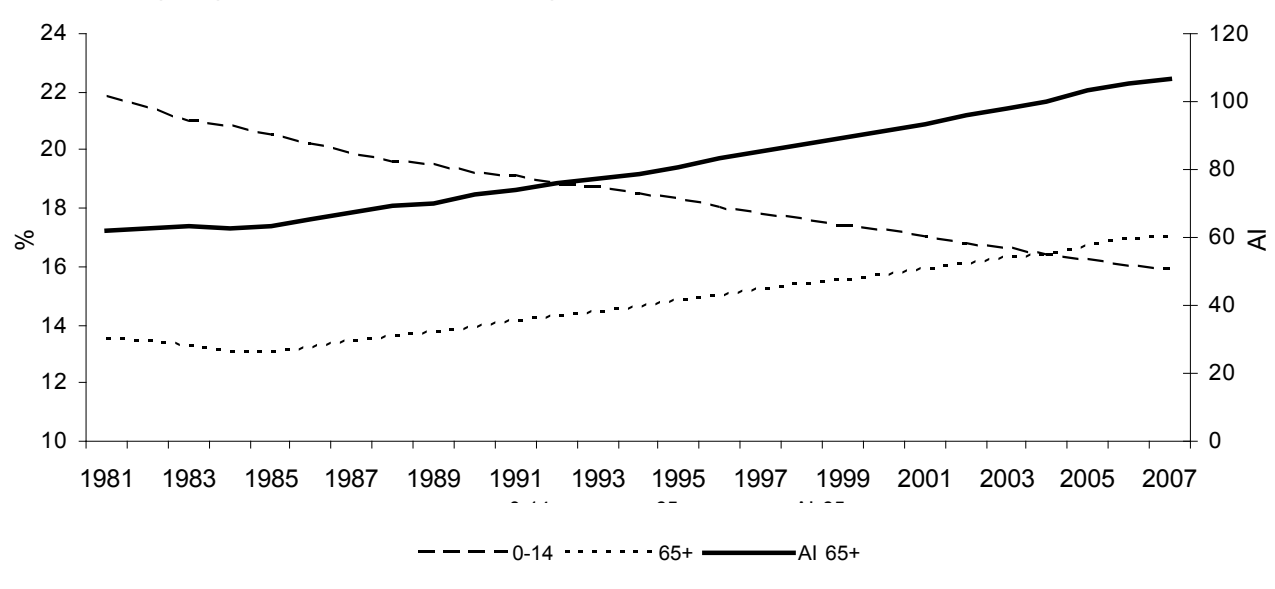

Source: Eurostat data + own calculations.

The long-term growth of the age accuracy indexes in individual EU countries can be seen in Figure 5 where there is on the panel 25 of time series an identical well-marked direction of their development (they differ only in speed with which the ageing comes about). Up to the end of the eighties of last century in all countries the proportion of children up to 15 was higher than the proportion of persons older than 65. In 1989 Sweden was the first country in the history of the EU where the shares of these two age-groups became equal and the index of ageing thus reached the value of 100 for the first time. Sweden is, however, relatively specific in this respect; its index of ageing was one of the highest up to the middle of the nineties, but it did not grow continually - phases of slow growth alternated with phases of slow decline and so the index oscillated throughout the period between the values of 90 and 100, the value of 100 not being passed for a second time until 2006. We record exponential growth and the long-term highest value of the index of ageing (in the years 1992-2006) in Italy, where the value of 100 was already achieved in 1992. Similar development to that in Italy can be seen in Spain, with a slight delay up to 2002. Although Spain was the third country to exceed the value of 100 in 1998, in the development of its index of ageing there was a turning-point in 2002 and since then its values have been slowly declining, a quite unique phenomenon in development in EU countries to date. On the opposite side in the imagined order we can find, throughout the period studied, Ireland where for 100 children there were between 36 and 55 persons over 65, Cyprus (42-69 persons) and Slovakia (35-74 persons).

After 2004 the unfavourable tendency in the growth of the values of the indexes of ageing of the EU countries (Table 4) continues (with the exception of Spain). The situation was particularly alarming in 2007 , when there were 12 countries with the proportion of persons over 65 greater than the proportion of children. In the comparison of the individual countries the worst off are Germany and Italy, where for 100 children there are almost 143 and 142 persons; the best off, on the other hand, is Ireland with just under 55 persons over the age of 65 for 100 children. 
Figure 5

Index of Ageing of EU25 countries in the years 1985-2007

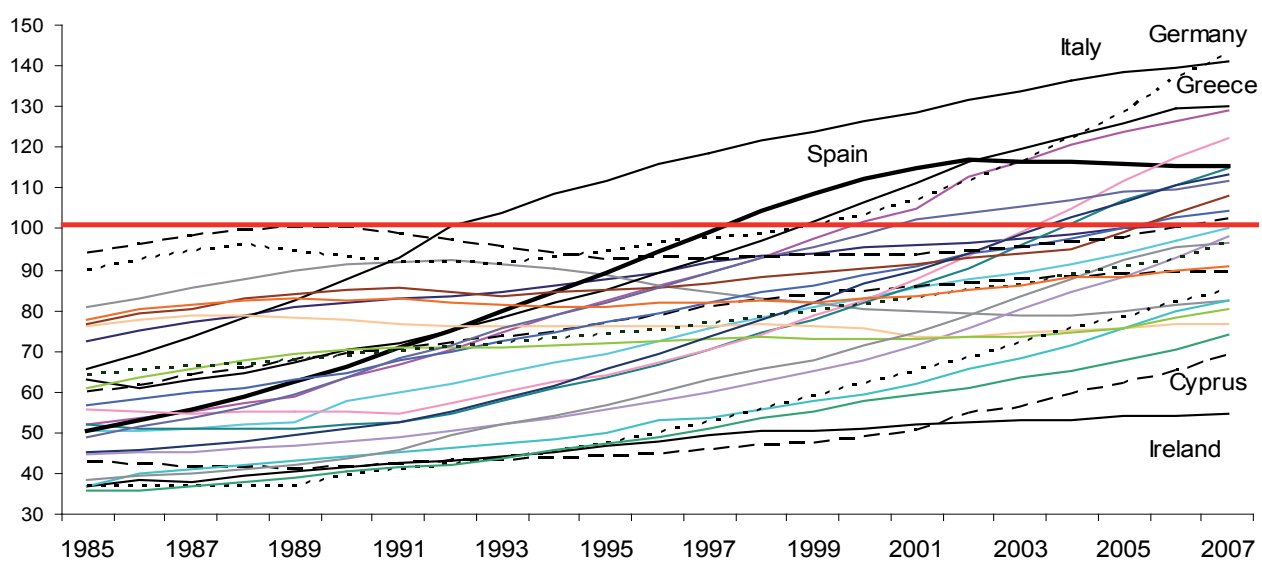

Source: Eurostat data + own calculations.

Table 4

Index of Ageing in the EU25 Countries in 2004 and 2007

\begin{tabular}{|c|c|c|c|c|c|}
\hline Country & 2004 & 2007 & Country & 2004 & 2007 \\
\hline Germany & 122,45 & 142,45 & Latvia & 84,75 & 98,11 \\
\hline Italy & 136,17 & 141,13 & Finland & 88,64 & 96,49 \\
\hline Greece & 122,76 & 130,07 & UK & 87,91 & 90,91 \\
\hline Lithuania & 105,19 & 122,14 & France & 88,11 & 89,13 \\
\hline Spain & 116,55 & 115,17 & Poland & 75,58 & 84,81 \\
\hline Estonia & 101,25 & 114,77 & Malta & 71,43 & 82,63 \\
\hline Slovenia & 102,74 & 113,57 & Denmark & 78,84 & 82,26 \\
\hline Portugal & 107,01 & 111,61 & Netherlands & 74,59 & 80,11 \\
\hline Austria & 95,09 & 108,33 & Luxembourg & 74,87 & 76,50 \\
\hline Hungary & 97,48 & 104,61 & Slovakia & 65,34 & 73,91 \\
\hline Sweden & 96,63 & 102,35 & Cyprus & 59,50 & 68,72 \\
\hline Belgium & 98,84 & 100,59 & Ireland & 53,11 & 54,68 \\
\hline Czech Republic & 91,45 & 100,00 & EU25 & 100,00 & 106,92 \\
\hline
\end{tabular}

Source: Eurostat data + own calculations.

From the given results it is evident that in the future migration can prevent a decline in the numbers of the populations of European countries, but it cannot prevent the ageing. It is therefore necessary to anticipate that the population will age and there will be more foreigners in individual countries. 


\section{Migration in the Czech Republic}

In the nineties the Czech Republic was an exception among the countries of the former Eastern bloc. First it became a transit country and then gradually also a target country for migrants. Migration behaviour is greatly influenced by the fact that the Czech Republic is one of the transforming countries of the so-called buffer zone. The opening of the borders did not evoke a massive emigration to the countries of Western Europe, but increasing the attraction of our republic as a transit country and gradually also as a target country for some immigrants (Figure 6).

Figure 6

Foreign Migration of the Czech Republic 1995-2007

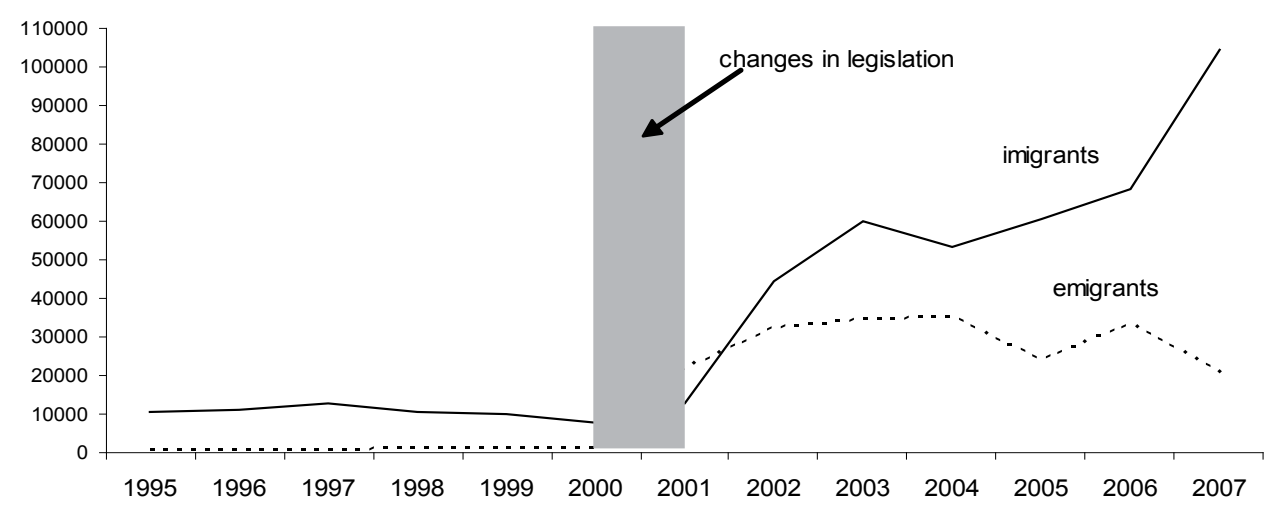

Source: data from the Czech Statistical Office.

The greatest movements in foreign migration are shown by the sphere of labour migration. The increase in foreigners who came to the Czech Republic to work is linked mainly to the shortage of qualified and unqualified manual workers on the labour market. In other sectors of the economy the level of wages is higher and so some of these professions are not attractive for the domestic population.

In all forms of labour migration the most represented from the long-term viewpoint are the Ukrainians and the Slovaks, then the Vietnamese, Russians and Poles. Foreigners from Western Europe and America have a considerably smaller share in our labour market. East European are more likely to work in manual professions; West Europeans, on the contrary, in highly specialised professions.

In the nineties the number of legally settled foreigners in the Czech Republic gradually increased (Figure 7, the total number of foreigners on the right-hand axis $y$ ). Between 1994 and 1999 the number more than doubled from around 100,000 to some 200,000 resident foreigners. In 2000 the number of foreigners dropped by 30,000, but this decline can be ascribed to changes in legislation. From the beginning of the year 2000 Act No. 326/1999 Coll., on the Residence of Foreigners on the Territory of the Czech Republic came into force in a form, which made the entry and residence regimes considerably stricter for the majority of foreigners in the Czech Republic. The amendment that came into effect on 1 July 2001 made some provisions of this 
law less strict and therefore resulted again in a slight increase in the number of settled foreigners (annually some tens of thousands of people), which continues up to the present.

Figure 7

Development of the Number of Foreigners in the Czech Republic in 1994-2007

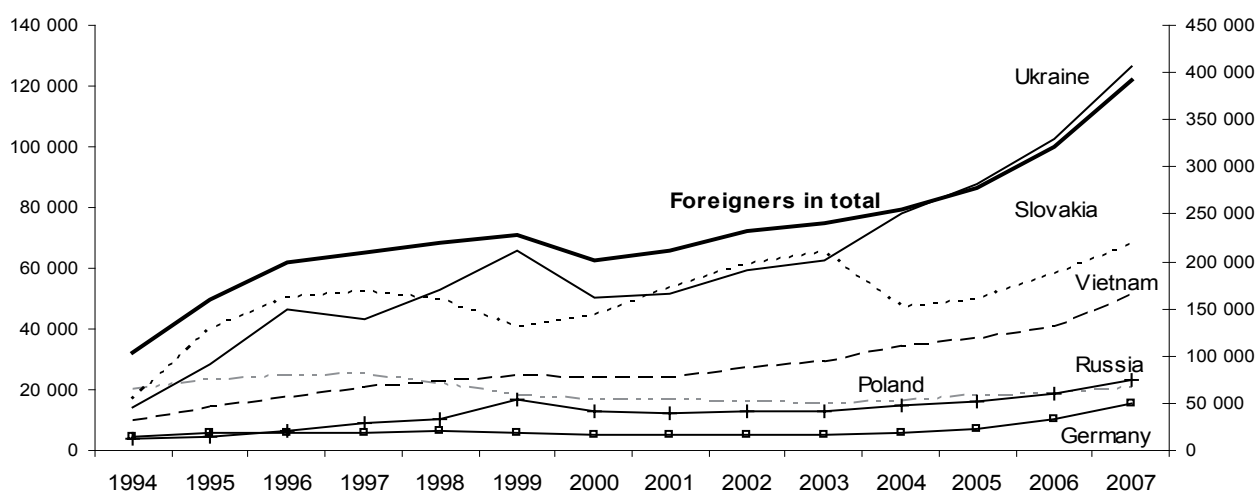

Source: data from the Czech Statistical Office.

In the Czech Republic as of 31 December 2007 there were 392,087 foreigners living in the Czech Republic, of which 158,018 had permanent residence and 234,069 foreigners with some of the types of long-term residence for over 90 days (i.e. temporary residence of EU citizens and their family members, then 90-day visas and long-term residence permits for citizens of countries outside the EU). Permanent or long-term resident foreigners accounted for $4 \%$ of the population in the Czech Republic and these were most frequently citizens of Ukraine, Slovakia, Vietnam, Russia, Poland and Germany.

Figure 8

Foreigners in the Czech Republic in 2007 according to State Citizenship

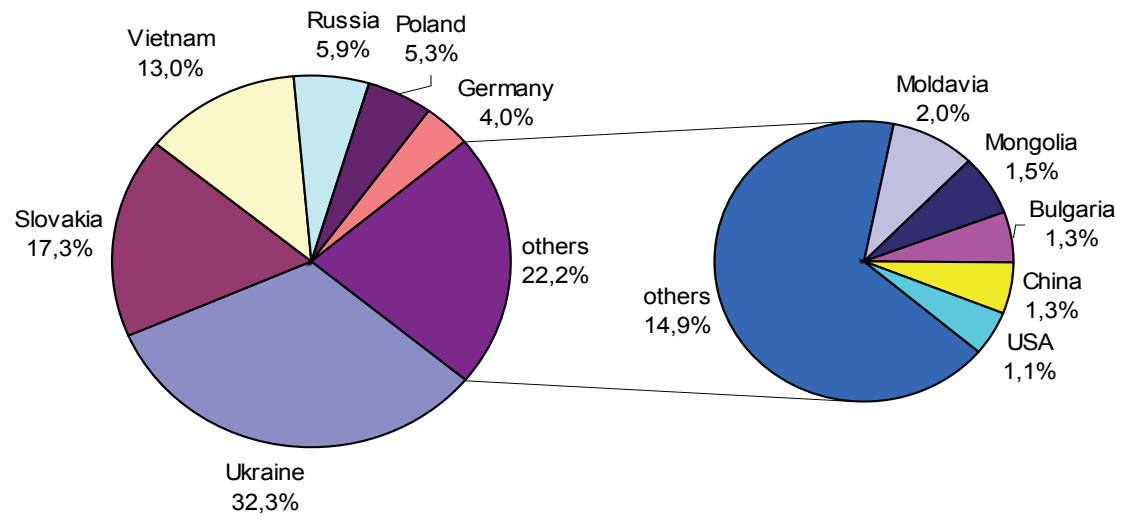

Source: data from the Czech Statistical Office. 


\subsection{Age Structure of Migrants in the Czech Republic}

The age structure of migrants in the Czech Republic differs considerably from the age structure of the domestic population (Figure 9). A considerable proportion of foreigners came to us and still do come mainly to work and to study. These are therefore persons of younger productive age (Figure 10). Moreover, those coming to work are more probably less qualified manpower and the men prevail - there are considerably less children and women.

Figure 9

Relative Age Structure of Foreigners and Citizens of the CR as of 1.1.2007

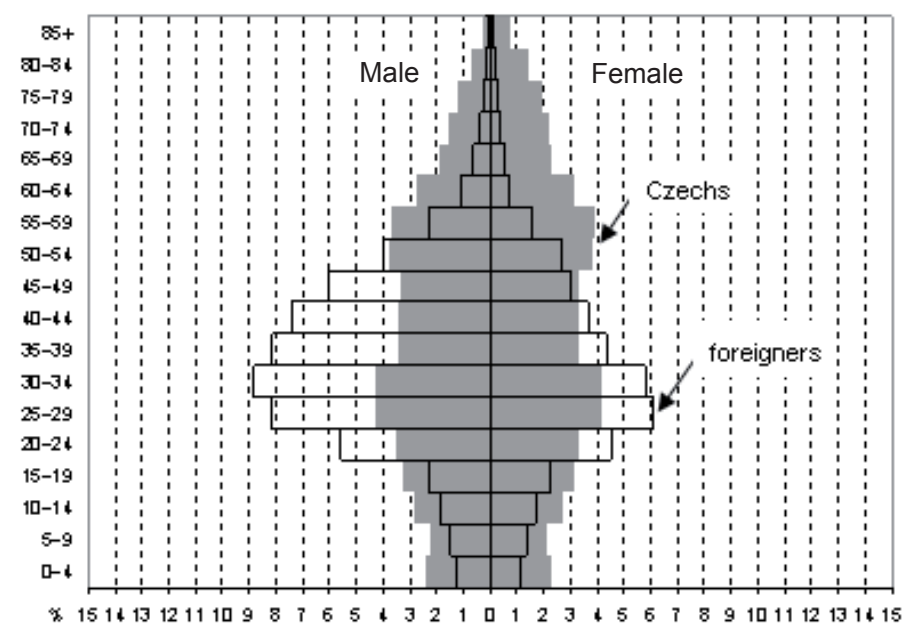

Source: data from the Czech Statistical Office.

Figure 10

Foreigners in the Czech Republic as of 1.1.2006 according to Year of Birth

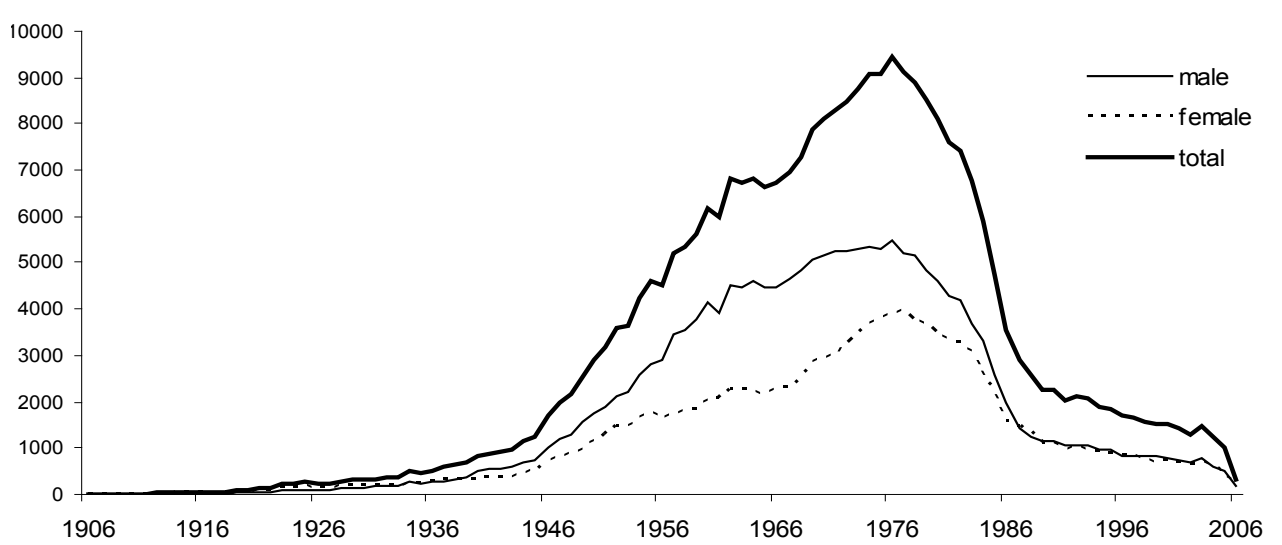

Source: Czech Ministry of the Interior. 
Migration from Slovakia has a specific standing in our country and often, due to the proximity of the Czechs and Slovaks, we do not even perceive it as migration. Slovaks are also most often awarded citizenship, which is also due to the fact that by law they may acquire citizenship by declaration. The main reason for migration was economic and a large proportion of students is also clear. There are large numbers of Slovak students at Czech universities and a considerable part of these remain here to live and work after completing their studies. The age structure of Slovak citizens is rather younger (Figure 11a). Almost $40 \%$ of the Slovaks living in the Czech Republic are aged 15-29 years.

\section{Figure 11}

Relative Age Structure of the Citizens of a) Slovakia and b) Ukraine with regard to the CR as of 1.1.2007
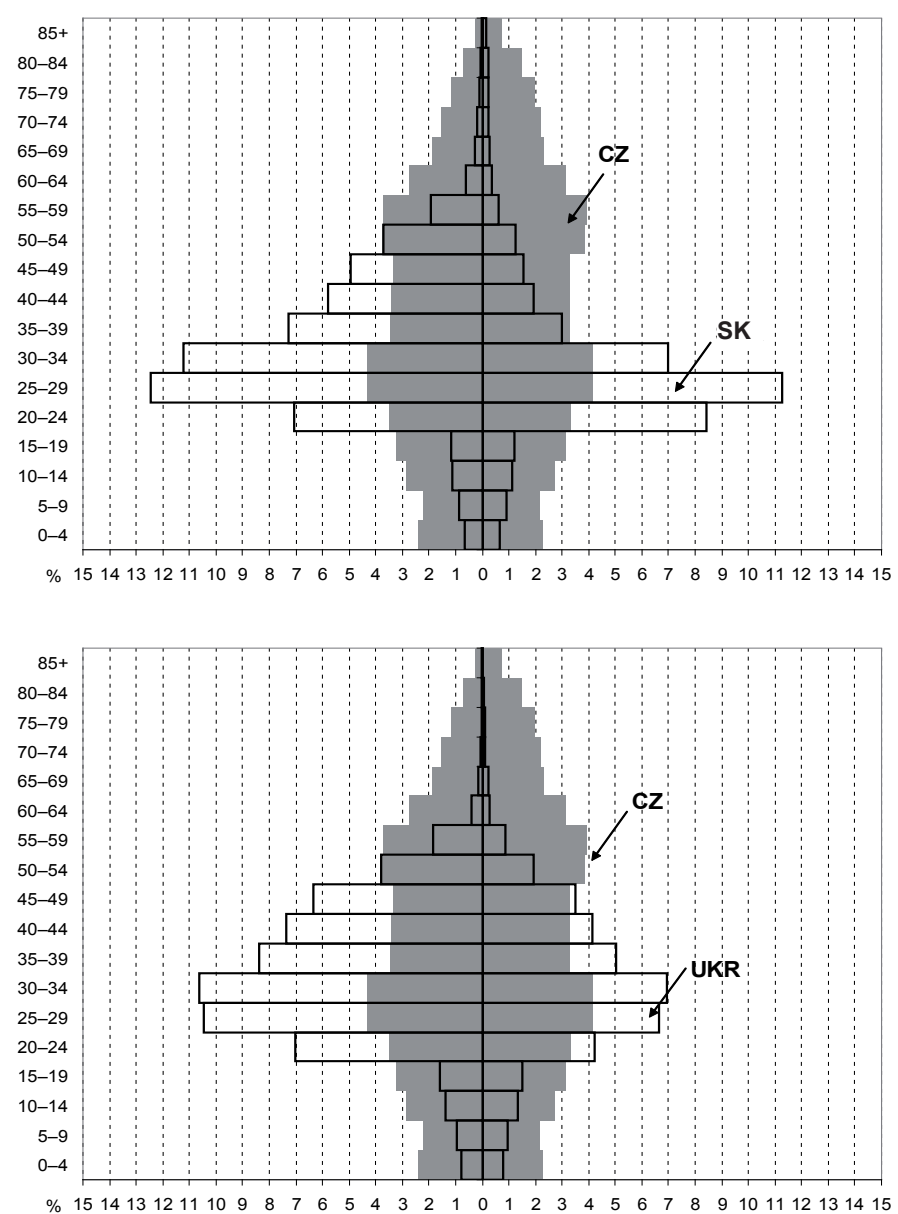

Source: Data from Czech Statistical Office. 
Citizens of Ukraine come to the Czech Republic mainly for economic reasons. This is typical for both genders, but in men it is more evident. The economic situation in Ukraine is not so good and the Czech Republic is therefore attractive to the Ukrainians and work is easier to find here. It is also a country that is geographically close and cultural and language barriers are low. The age structure of citizens from Ukraine is therefore typical of labour migration (Figure 11b). Almost $93 \%$ of the Ukrainians are of productive age 15-59 years, but most are aged between 20 and 45 . There are increasing numbers of children among migrants from Ukraine, meaning that a part of them live here with the whole family.

Figure 12

Relative Age Structure of Citizens of a) Vietnam and b) Poland with regard to the $C R$ as of 1.1.2007
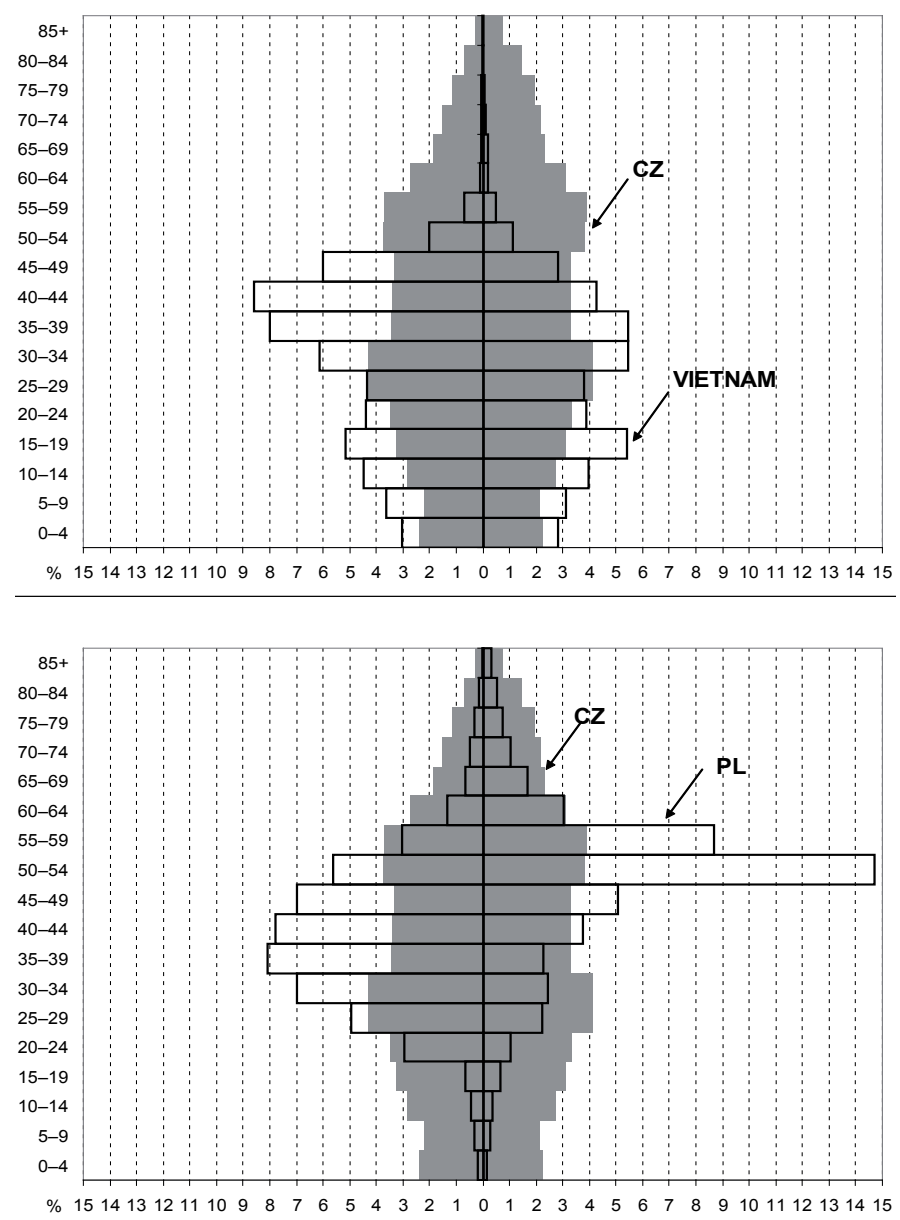

Source: Data from: Czech Statistical Office. 
Vietnamese citizens began coming to Czechoslovakia already in the fifties of last century to study and later also to work. The largest numbers of arrivals, mainly men, were in the eighties. At present the migration of Vietnamese people has somewhat different traits. They come to us in order to unite the family and to settle permanently. The Vietnamese migrate to our country as the whole families and some of the children were born here. The age category of 35-50 years is very strongly represented (Figure 12a). There are also striking numbers of women and children. A considerable part of the Vietnamese is economically active and the age structure is progressive compared to the others. There is a high proportion of children here and a very small number of persons over the age of 60 .

Migrants from Poland do not have any very strong traits. It was particularly women who came to this country in the seventies and eighties of last century to work in manual professions. Polish women also more frequently marry the Czechs and are not therefore registered as foreigners here. The age structure of Polish citizens is older in comparison with the age structures of other foreigners (Figure 12b). More than half the Poles living in the Czech Republic are over the age of 45.

People from Russia also arrive here due to the bad social-economic situation at home. There are a considerable number of students among them. If the Russians move, then the whole family moves, which is also demonstrated by their age structure (Figure 13). Women are represented more than men. The age categories are evenly distributed.

Figure 13

Relative Age Structure of Citizens of Russia with Regard to the CR as of 1.1.2007

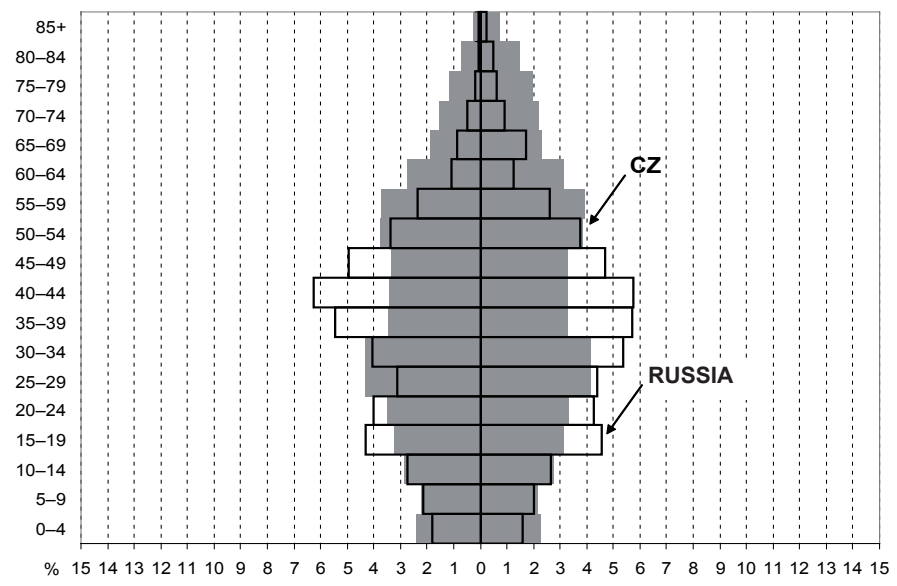

Source: Data from: Czech Statistical Office. 
It can therefore be stated that typical age and gender structure of foreigners is the prevalence of men - men account for roughly $60 \%$ of all foreigners. Among foreigners there is a prevalence of persons of productive age (between 22 and 49 years). Most foreigners are from Ukraine, Slovakia, Vietnam, Russia and Poland.

If we look at the citizenship from the viewpoint of allocation of permanent residence, the first there is Vietnam, followed by Ukraine, Slovakia, Poland, Russia and Germany. From the viewpoint of long-term stays there are most the Ukrainians and Slovaks, then Vietnamese, Russians, Germans and Poles. The people who come to us from surrounding countries come mainly to work. There are more long-term stays here in comparison with permanent residence. The opposite is true in the case of citizens from Vietnam who have come with the aim of settling here and for this reason there is also a clear higher percentage of permanent residence among them. There are gender differences from the viewpoint of purpose of stay. Men come more to work and women to unite the family.

\subsection{Influence of Migrants on the Numbers and Ageing of the Population in the Czech Republic}

Since the beginning of the nineties of last century there has been a large drop in the number of inhabitants thanks to the negative natural increase and even the gradual increase in the number of immigrants was not able to reverse this trend. The change did not take place until 2003, when there was a strong increase in the number of immigrants and the number of inhabitants of the Czech Republic began to rise again after many long years. The positive influence of migration on the growth of the total number of inhabitants of the Czech Republic can thus be seen in Figure 14. From 2006 the natural increase has also shared in the positive development of the number of inhabitants.

Figure 14

Natural Increase and Increment through Migration for the Czech Republic

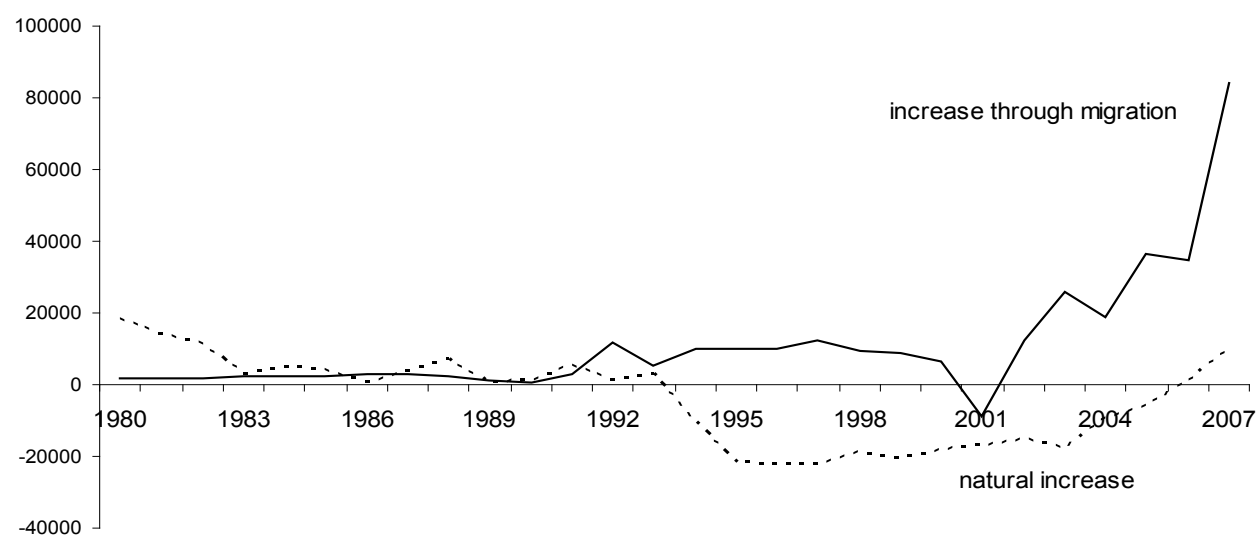

Source: data from the Czech Statistical Office. 
From the available data it is evident that the positive natural increase in recent years is not influenced by the growing migration. The numbers of children born to foreigners are so far negligible - in 2006 they accounted for $1.63 \%$ and in 2007 for $1.83 \%$ of all children born in the Czech Republic.
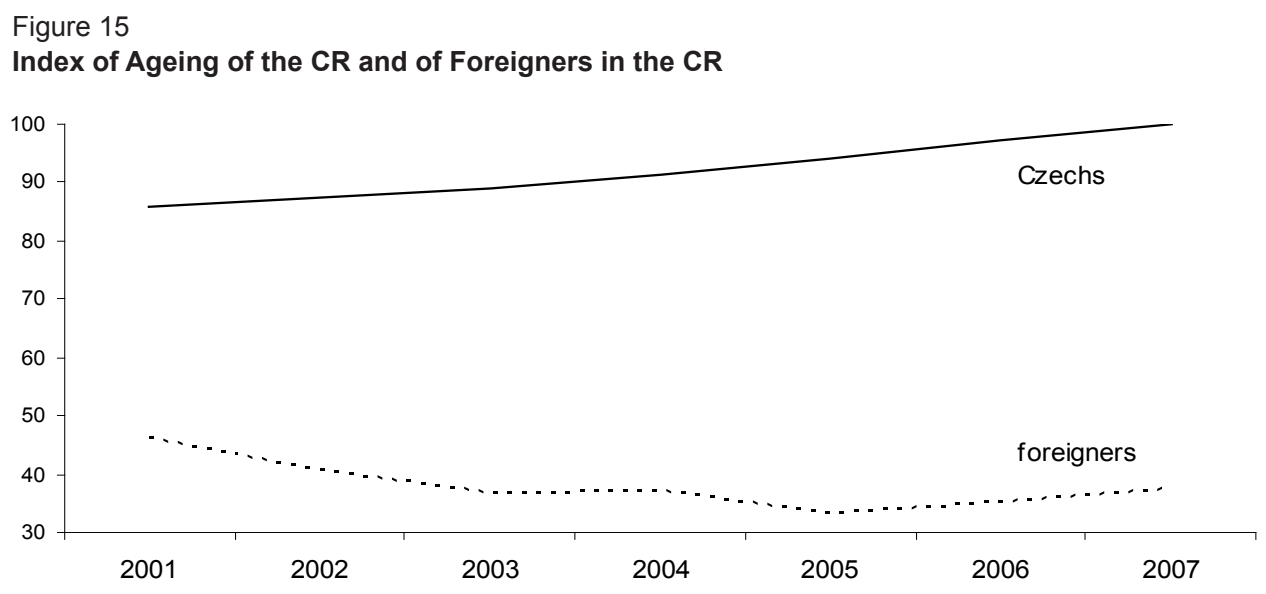

Source: data from the Czech Statistical Office.

From Figure 15 even the positive influence of the relatively young age structure of foreigners on the index of ageing of inhabitants of the Czech Republic is not evident. The index of ageing of foreigners living in the Czech Republic has been long-term below 40\%, but this is unable to prevent the gradual rise in this index for the Czech Republic as a whole. The Czech Republic is at present among those European countries that have a very low proportion of children in the population. This is caused by the fact that the fertility of Czech women is far below the so-called maintenance level of simple reproduction. From the viewpoint of the index of ageing the Czech Republic is somewhere in the middle among the EU countries. The value of $100 \%$ and thus the equalisation of the proportions of children under 15 and persons over the age of 65 was achieved in 2007. It is very probable that, in spite of the increasing numbers of children born, the index of ageing of the inhabitants of the Czech Republic will also continue to rise in the future.

\section{Conclusion}

At present the problem of the ageing is coming to the forefront of society's interest. Never before in the existence of humanity there has been such rapid ageing of population in the advanced countries. The Czech Republic will also age and it will age unintentionally fast. From the available data and from the analyses carried out, however, we cannot support the opinion that the ageing in the EU and the Czech Republic can be prevented by immigration. The period studied is, however, relatively short and in the future development may change completely. 
The migration for the EU countries is unavoidable in the future. It will not prevent the ageing of the population, probably it will only partially slow it down, but it may have a positive influence on the numbers of inhabitants. The consequence of this will be, of course, an increase in the proportion of foreigners in the population. Qualified immigrants are needed for the labour market and mean a higher number of taxpayers, which will be necessary to finance a sustainable standard of living not only for seniors. Migrants will not, however, be solely a benefit; they will also bring with them a number of problems that we will have to deal with in the future. The first and perhaps the most serious of these is happening now when the present economic crisis hits the EU countries, not excepting the Czech Republic. Unemployment is rising and the employers will first of all lay off mainly foreigners in less qualified jobs. States are facing a situation where they must prevent these workers from spilling over into illegality and causing subsequently an increase in crime. It is therefore possible to expect that in the next few months and possibly years the influx of new work migrants will stagnate or even drop. With an economic boom, however, they will again increase in numbers and the individual EU states should be prepared in advance.

\section{References:}

Arlt, J., Arltová, M. (2009), Ekonomické časové řady. Praha: Professional Publishing.

Arltová, M., Langhamrová, J. (2009), "Analýza vztahů časových řad porodnosti a sňatečnosti v České republice v letech 1960-2007.” Politická ekonomie, 2009, Vol. 57, No. 4, pp. 495-508.

Barša, P. (2003), "Managing Immigration and Integration in Europe and in the Czech Republic." Final Research Paper. International Policy Fellowships. http://www.policy.hu/barsa/Final_Research_ Paper_html.html.

Czech Statictical Office (2009), "Počet cizinců v ČR.” http://www.czso.cz/csu/cizinci.nsf/o/ciz_pocet_ cizincu-popis_aktualniho_vyvoje.

Fiala, T., Langhamrová, J. (2008), "Vliv migrace na budoucí demografický vývoj." Mezinárodní politika 6, 2008, pp. 10-14.

Gladišová, L. (2004), "Migrační trendy v Evropě na počátku třetího tisíciletí," in Za prací do Evropy. Člověk v tísni - společnost při ČT, o. p. s. http://www.migraceonline.cz/doc/_brozura\%20EU\%20 $10 \% 20$ web.pdf.

Horáková, M. (2005), "Řízení nových imigračních toků: Řízení migrace v nových členských zemích EU - Česká republika." VÚPSV ČR. http://www.vupsv.cz/Fulltext/Do_1434.pdf.

Kadeřábková, A. (2006): “Česká republika v globalizované a znalostně založené ekonomice: vývojové trendy a politické implikace." http://www.zavedenieura.cz/cps/rde/xbcr/mfcr/Studie_Ceska_ republika_globalizace200612_pdf.pdf

Kepka, J. (2008), "Problémy imigrace v evropském kontextu - Praktická opatření pro ČR." E-polis. $c z, 2008$. http://www.e-polis.cz/evropska-unie/319-problemy-imigrace-v-evropskem-kontextuprakticka-opatreni-pro-cr.html.

Koschin, F., Fiala, T., Kačerová, E., Krebs, V., Langhamrová, J. (2004), "How to Deal with the Economic Consequences of the Ageing of Our Population." University of Economics, Prague.

Langhamrová, J. (2005), "Zachrání nás imigranti?" in Vaňo, B. (ed.). Naša demografia - súčasnost' a perspektívy. Bratislava: SŠDS, pp. 119-124.

Langhamrová, J., Kačerová, E. (2007), "Věkové složení cizinců v České republice." Forum Statisticum Slovacum III (3), pp. 157-161. 
Nezávislé sociálně ekologické hnutí (NESEHNUTí) "Migrace a uprchlictví v dějinách lidstva." http:// uprchlik.ecn.cz/cz/historie.html.

Sobotka, T. (2008), "The Rising Importance of Migrants for Childbearing in Europe." Demographic Research 19 (9), pp. 225-248.

Other resources:

Czech Statistical Office (http://www.czso.cz)

Eurostat (http://epp.eurostat.ec.europa.eu)

Ministry of the Interior of the Czech Republic (http://www.mvcr.cz) 